\title{
Article \\ Dose-Dependent Effects of Resveratrol on Cisplatin-Induced Hearing Loss
}

\author{
Chang Ho Lee, Kyung Woon Kim, So Min Lee and So Young Kim * \\ Department of Otorhinolaryngology-Head \& Neck Surgery, CHA University College of Medicine, \\ Seongnam 13496, Korea; hearwell@gmail.com (C.H.L.); wgaltz@naver.com (K.W.K.); \\ lws6812@naver.com (S.M.L.) \\ * Correspondence: sossi81@hanmail.net; Tel.: +82-31-870-5340; Fax: +82-31-870-5346
}

\section{check for} updates

Citation: Lee, C.H.; Kim, K.W.; Lee, S.M.; Kim, S.Y. Dose-Dependent Effects of Resveratrol on CisplatinInduced Hearing Loss. Int. J. Mol. Sci. 2021, 22, 113. https://dx.doi.org/ $10.3390 /$ ijms 22010113

Received: 24 November 2020 Accepted: 22 December 2020 Published: 24 December 2020

Publisher's Note: MDPI stays neutral with regard to jurisdictional claims in published maps and institutional affiliations.

Copyright: () 2020 by the authors. Licensee MDPI, Basel, Switzerland. This article is an open access article distributed under the terms and conditions of the Creative Commons Attribution (CC BY) license (https: / / creativecommons.org/ licenses/by/4.0/).
Abstract: Previous preclinical studies have demonstrated the otoprotective effects of resveratrol (RV) at low doses. This study aimed to investigate the dose-dependent effects of RV in rats with cisplatin (CXP)-induced hearing loss. Sprague-Dawley rats (8-weeks old) were divided into six treatment groups ( $n=12$ /group) and treated as follows: control, $0.5 \mathrm{mg} / \mathrm{kg} \mathrm{RV}, 50 \mathrm{mg} / \mathrm{kg} \mathrm{RV}, \mathrm{CXP}$, $0.5 \mathrm{mg} / \mathrm{kg} \mathrm{RV}+\mathrm{CXP})$, and $50 \mathrm{mg} / \mathrm{kg} \mathrm{RV}+\mathrm{CXP}$ groups. CXP $(3 \mathrm{mg} / \mathrm{kg})$ was intraperitoneally injected for 5 days. RV ( 0.5 or $50 \mathrm{mg} / \mathrm{kg}$ ) was intraperitoneally injected for 10 days from the first day of CXP administration. Auditory brainstem response (ABR) thresholds were measured before and within 3 days at the end of the drug administration. Cochlear tissues were harvested, and the outer hair cells were examined using cochlear whole mounts. The mRNA expression of NFkB, IL6, $I L 1 \beta$, and CYP1A1, and protein levels of aryl hydrocarbon receptor (AhR) and cytosolic and nuclear receptor for advanced glycation endproducts (RAGE) were evaluated. The ABR threshold increased in the $50 \mathrm{mg} / \mathrm{kg} \mathrm{RV}$ and CXP groups at 4, 8, 16, and $32 \mathrm{kHz}$. The $0.5 \mathrm{mg} / \mathrm{kg} \mathrm{RV}+\mathrm{CXP}$ group demonstrated decreased hearing thresholds at 4 and $32 \mathrm{kHz}$ compared to the CXP group. Cochlear whole-mount analysis revealed loss of outer hair cells in the $50 \mathrm{mg} / \mathrm{kg} \mathrm{RV}$ and CXP groups and partial prevention of these cells in the $0.5 \mathrm{mg} / \mathrm{kg} \mathrm{RV}+\mathrm{CXP}$ group. The mRNA expressions of NF $k B$, IL6, and IL1 $\beta$ were increased in the $50 \mathrm{mg} / \mathrm{kg}$ RV and CXP groups compared to the control group. In contrast, these levels were decreased in the $0.5 \mathrm{mg} / \mathrm{kg} \mathrm{RV}+\mathrm{CXP}$ group compared to the CXP group. The mRNA expression of CYP1A1 was increased in the CXP group, while it was decreased in the $0.5 \mathrm{mg} / \mathrm{kg} \mathrm{RV}+\mathrm{CXP}$ group compared to the control group. The protein levels of AhR and cytosolic RAGE decreased in the $0.5 \mathrm{mg} / \mathrm{kg}$ RV group. Low-dose RV had partial otoprotective effects on CXP ototoxicity. The otoprotective effects of RV may be mediated through anti-oxidative (CYP1A1 and RAGE) and anti-inflammatory (NFKB, IL6, and IL1 $\beta$ ) responses. High-dose RV exerted an inflammatory response and did not ameliorate CXP-induced ototoxicity.

Keywords: hearing loss; cisplatin; resveratrol; nuclear factor kappa B; aryl hydrocarbon receptor

\section{Introduction}

Resveratrol (trans-3, $4^{\prime}, 5$,-trihydroxystilbene, RV) is a natural polyphenol abundant in grape skin [1]. RV is the key compound responsible for the "French paradox", which refers to a reduced risk of coronary heart disease in the French population, despite its highsaturated-fat diet [2]. A moderate dose of RV has been reported to have protective effects on cardiovascular diseases through anti-oxidative effects, mediated by scavenging peroxyl radicals and impeding lipid peroxidation, and anti-inflammatory effects, via several target molecules, including nuclear factor kappa B (NFkB) [3]. Additionally, increasing evidence supports the anti-proliferative and anti-angiogenic effects of RV, and RV-mediated effects have been implicated in multiple conditions, from cardiovascular and neurodegenerative diseases to cancer and longevity [4].

The effects of RV vary depending on its bioavailability and dose. The bioavailability of $\mathrm{RV}$ is dependent on the administration route and is affected by the food matrix. When 
administered orally, the sulfated form is the main metabolite in human plasma and limits the bioavailability of RV [5]. The absorptive efficiency is influenced by the constituents, and only about $1.7-1.9 \%$ of orally administered resveratrol was accounted for as biologically active free polyphenol [6]. In in vitro studies, a high dose of RV $\left(10^{-5}-10^{-4} \mathrm{M}\right)$ has been tested for cancer chemoprevention effects, which is much higher than in the in vivo doses [7]. In addition, the dose-dependent effects of RV have been reported to include anti-apoptotic and cardioprotective effects at low doses and pro-apoptotic and vascular endothelial injuries at high doses [8].

A number of preclinical studies have reported the protective effects of RV in animals with hearing loss induced by aging [9-11], noise [12,13], aminoglycoside [14,15], and cisplatin [16-18]. The plausible mechanisms of these otoprotective effects of RV include amelioration of oxidative stress and inflammation [15] and restoration of autophagy [19]. However, a dose-dependent otoprotective effect of RV was suggested in a cisplatin-induced rat study [20]. The study showed a hearing-preservation effect of RV on cisplatin-administered rats at a low dose of $0.1 \mathrm{mg} / \mathrm{kg} /$ day of RV for 10 days, whereas enhanced ototoxicity was observed at high doses of 1 or $10 \mathrm{mg} / \mathrm{kg} /$ day of RV for 10 days [20]. Another noise-induced rat study demonstrated no significant hearing preservation effect with $30 \mathrm{mg} / \mathrm{kg}$ of $\mathrm{RV}$ in rats [21].

We hypothesized that there exists a dose range for the otoprotective effect of RV. To test this hypothesis, rats were administered low $(0.5 \mathrm{mg} / \mathrm{kg} /$ day $)$ or high $(50 \mathrm{mg} / \mathrm{kg} /$ day $)$ doses of RV based on a previous study that demonstrated no protective effect of RV at $50 \mathrm{mg} / \mathrm{kg}$ in the vascular endothelial function in rats [22].

\section{Results}

\subsection{ABR Threshold Shift Following CXP and/or RV Administration}

Among the six groups, four groups (other than control and $0.5 \mathrm{mg} / \mathrm{kg} \mathrm{RV}$ groups) demonstrated ABR threshold shifts following drug administration (Figure 1). Although the control and $0.5 \mathrm{mg} / \mathrm{kg} \mathrm{RV}$ groups did not show increased hearing thresholds after drug administration, the $50 \mathrm{mg} / \mathrm{kg} \mathrm{RV}$ group demonstrated increased hearing threshold at 4, 8, 16 , and $32 \mathrm{kHz}(23.75 \pm 1.83$ vs. $45.45 \pm 3.12 \mathrm{~dB} \mathrm{SPL}, p<0.001$ for $4 \mathrm{kHz}, 26.25 \pm 2.63$ vs. $49.29 \pm 1.95 \mathrm{~dB}$ SPL, $p<0.001$ for $8 \mathrm{kHz}, 27.50 \pm 2.50$ vs. $46.43 \pm 3.57 \mathrm{~dB}$ SPL, $p=0.001$ for $16 \mathrm{kHz}$, and $41.25 \pm 1.25$ vs. $61.43 \pm 2.94 \mathrm{~dB}$ SPL, $p=0.02$ for $32 \mathrm{kHz}$ ). Cisplatin administration induced elevation of the hearing threshold. The CXP group demonstrated increased hearing threshold after CXP injection at $4,8,16$, and $32 \mathrm{kHz}(30.00 \pm 1.21 \mathrm{vs}$. $52.94 \pm 3.61 \mathrm{~dB}$ SPL, $p<0.001$ for $4 \mathrm{kHz}, 31.67 \pm 1.85$ vs. $51.11 \pm 2.79 \mathrm{~dB}$ SPL,$p<0.001$ for $8 \mathrm{kHz}, 32.22 \pm 2.22$ vs. $49.44 \pm 3.28 \mathrm{~dB}$ SPL, $p<0.001$ for $16 \mathrm{kHz}$, and $44.44 \pm 1.21 \mathrm{vs}$. $55.00 \pm 2.32 \mathrm{~dB}$ SPL, $p<0.001$ for $32 \mathrm{kHz}$ ). The $50 \mathrm{mg} / \mathrm{kg} \mathrm{RV}+\mathrm{CXP}$ group demonstrated increased hearing threshold after CXP injection at $4,8,16$, and $32 \mathrm{kHz}$, and the hearing thresholds after drug administration (post) were not significantly different from those of the CXP group $(25.39 \pm 1.44$ vs. $51.82 \pm 4.64 \mathrm{~dB} \mathrm{SPL}, p<0.001$ for $4 \mathrm{kHz}, 26.00 \pm 1.31$ vs. $57.69 \pm 3.95 \mathrm{~dB}$ SPL, $p<0.001$ for $8 \mathrm{kHz}, 30.00 \pm 1.48$ vs. $50.00 \pm 4.26 \mathrm{~dB}$ SPL, $p<0.001$ for $16 \mathrm{kHz}$, and $40.00 \pm 1.48$ vs. $56.67 \pm 1.42 \mathrm{~dB}$ SPL, $p<0.001$ for $32 \mathrm{kHz}$ ). The $0.5 \mathrm{mg} / \mathrm{kg} \mathrm{RV}$ + CXP group also demonstrated increased hearing threshold after CXP injection at 4, 8, 16, and $32 \mathrm{kHz}$, but the hearing thresholds after drug administration (post) were lower than those of the CXP group at 4 and $32 \mathrm{kHz}(29.09 \pm 1.46$ vs. $37.50 \pm 2.14 \mathrm{~dB}$ SPL, $p=0.008$ ( $p=0.02$, vs. CXP group, unpaired $t$-test) for $4 \mathrm{kHz}, 35.91 \pm 1.82 \mathrm{vs} .46 .25 \pm 4.91 \mathrm{~dB}$ SPL, $p=0.034$ for $8 \mathrm{kHz}, 33.64 \pm 1.55$ vs. $41.88 \pm 4.76 \mathrm{~dB}$ SPL, $p=0.071$ for $16 \mathrm{kHz}$, and $41.82 \pm$ 1.26 vs. $40.00 \pm 2.04 \mathrm{~dB}$ SPL, $p=0.576$ ( $p=0.05$, vs. CXP group, unpaired $t$-test) for $32 \mathrm{kHz}$ ). 

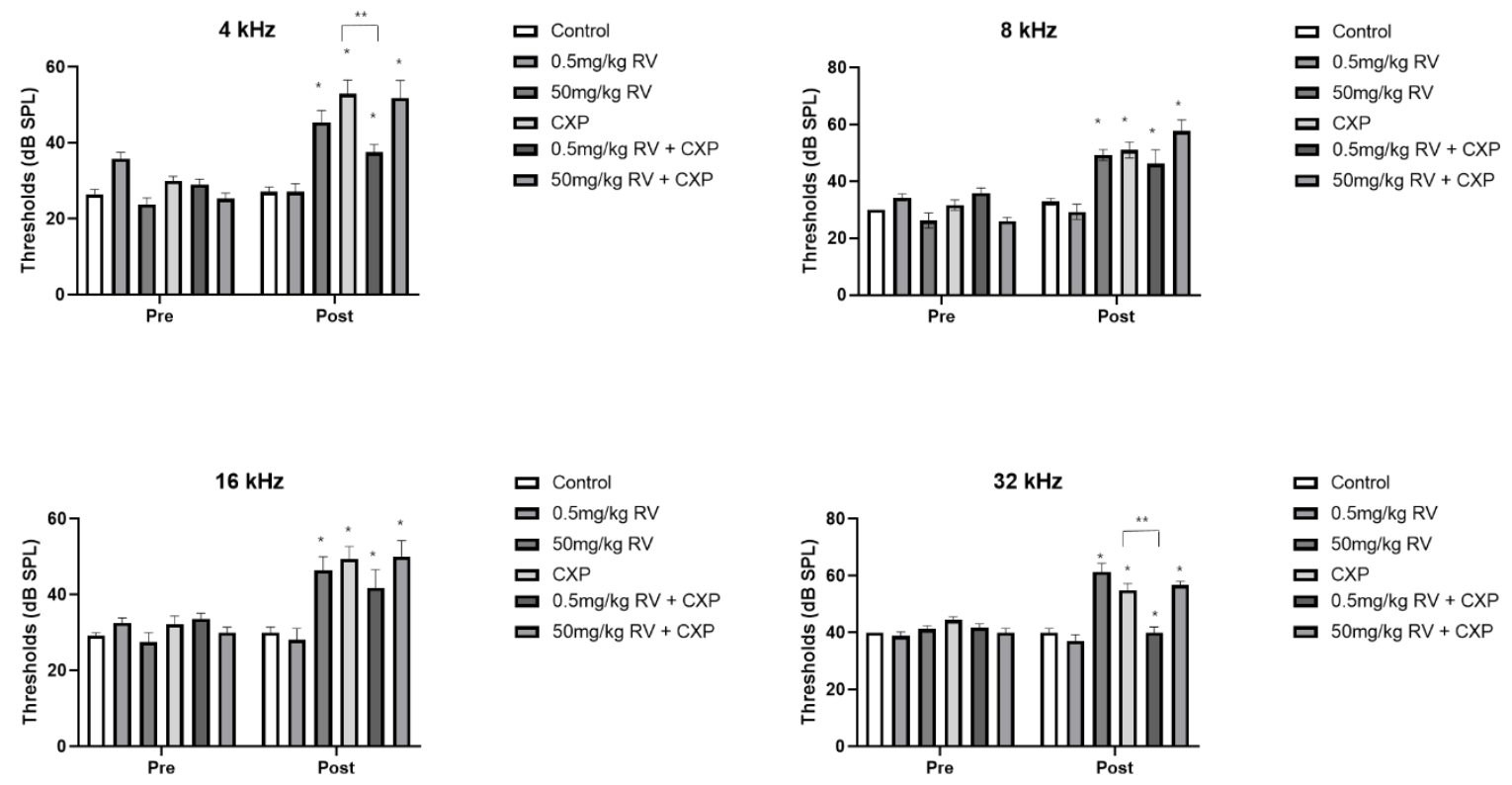

Figure 1. The auditory brainstem response thresholds of each group. The $50 \mathrm{mg} / \mathrm{kg} \mathrm{RV}+\mathrm{CXP}$ group demonstrated increased hearing thresholds that were not significantly different from those of the CXP group. In the $0.5 \mathrm{mg} / \mathrm{kg} \mathrm{RV}+\mathrm{CXP}$ group. the hearing thresholds after drug administration were lower than those of the CXP group at 4 and $32 \mathrm{kHz}\left({ }^{*} p<0.05\right.$, pre- vs. post-treatment, ${ }^{* *} p<0.05$, CXP vs. $0.5 \mathrm{mg} / \mathrm{kg}$ RV + CXP groups).

\subsection{Cochlear Outer Hair Cell Injury}

Cochlear whole-mount examination revealed a loss of outer hair cells in the $50 \mathrm{mg} / \mathrm{kg}$ $\mathrm{RV}$ group (Figure 2). CXP administration caused disorientation and reduction of the outer hair cells. These outer hair cell injuries were attenuated in the $0.5 \mathrm{mg} / \mathrm{kg} \mathrm{RV}+\mathrm{CXP}$ group but not in the $50 \mathrm{mg} / \mathrm{kg} \mathrm{RV}+\mathrm{CXP}$ group.

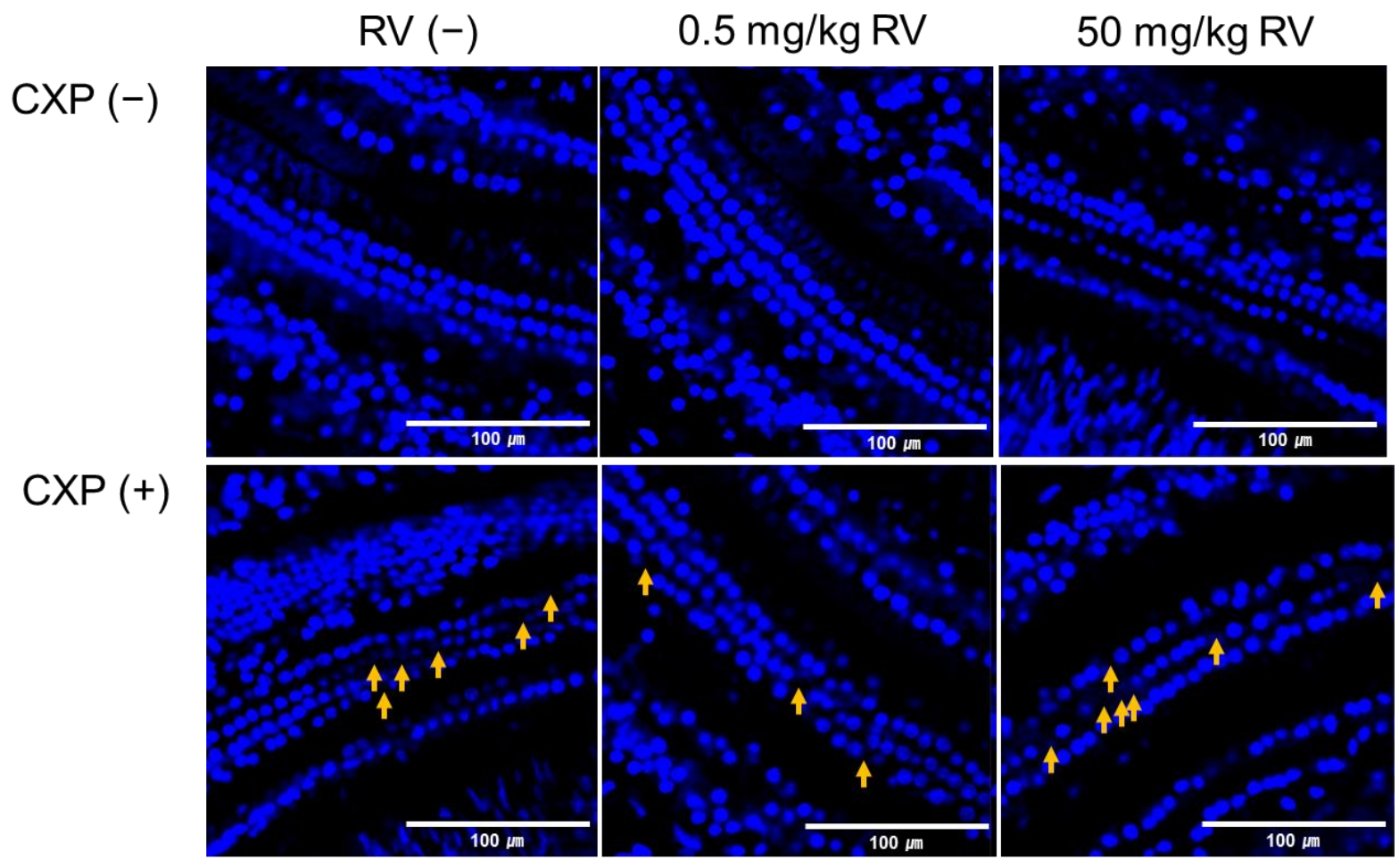

Figure 2. The loss of outer hair cells were noted in the $50 \mathrm{mg} / \mathrm{kg}$ RV group. (yellow arrow: loss of outer hair cells). 
2.3. Increased NFKB, IL1 $\beta$, and IL6 and Decreased CYP1A1 Levels in CXP-Induced Hearing Loss Rats and Partial Reversal of Expression Patterns Following $0.5 \mathrm{mg} / \mathrm{kg}$ RV Treatment

The CXP group showed significantly higher mRNA levels of $N F \kappa B$, IL1 $\beta$, and IL6 $(1.63 \pm 0.14(p=0.001), 2.22 \pm 0.39(p=0.03)$, and $2.25 \pm 0.24(p=0.02)$ fold change, respectively) compared to the control group (Figure 3). The $50 \mathrm{mg} / \mathrm{kg} \mathrm{RV}$ group and the $50 \mathrm{mg} / \mathrm{kg}$ RV + CXP groups showed higher mRNA levels of NFKB (1.58 \pm 0.16 fold, $p=0.005$ for $50 \mathrm{mg} / \mathrm{kg}$ RV group and $1.68 \pm 0.20$ fold, $p=0.007$ for $50 \mathrm{mg} / \mathrm{kg} \mathrm{RV}+\mathrm{CXP}$ group) compared to the control group. The $0.5 \mathrm{mg} / \mathrm{kg} R V$ group and $0.5 \mathrm{mg} / \mathrm{kg} \mathrm{RV}+\mathrm{CXP}$ group did not show a significant change in mRNA levels of $N F \kappa B, I L 1 \beta$, and IL6, compared to the control group.
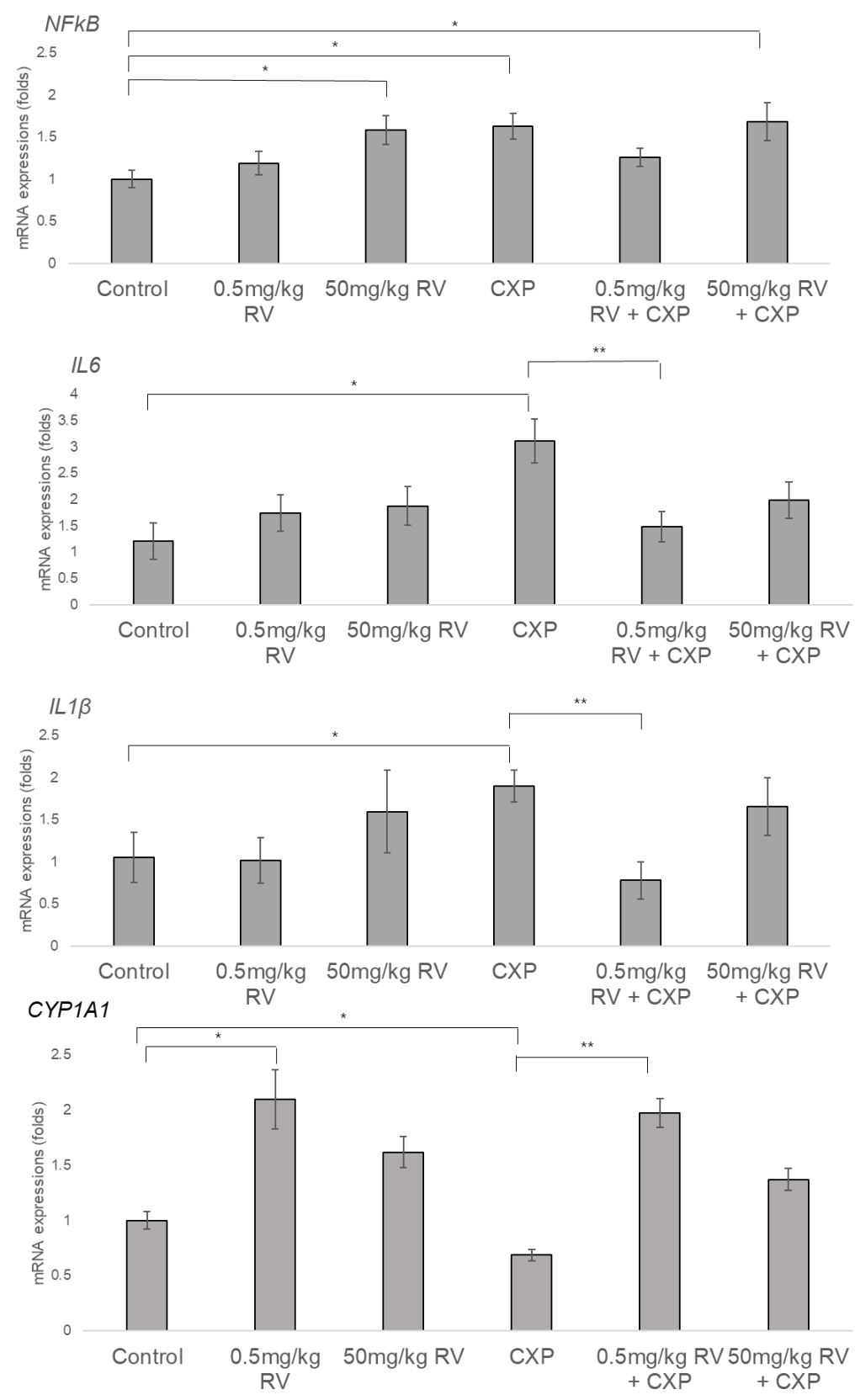

Figure 3. Compared to the CXP group, the $0.5 \mathrm{mg} / \mathrm{kg} \mathrm{RV}+\mathrm{CXP}$ group showed decreased mRNA levels of $N F \kappa B$, IL1 $\beta$, and $I L 6$. The $50 \mathrm{mg} / \mathrm{kg} \mathrm{RV}+\mathrm{CXP}$ group did not show any significant difference in mRNA levels of $N F \kappa B, I L 1 \beta$, and IL6 compared to the CXP group. The mRNA level of CYP1A1 was increased in the $0.5 \mathrm{mg} / \mathrm{kg}$ RV group and $0.5 \mathrm{mg} / \mathrm{kg} \mathrm{RV}+$ CXP group. $\left({ }^{*} p<0.05\right.$, compared to control group, ${ }^{* *} p<0.05$, compared to CXP group). 
Compared to the CXP group, the $0.5 \mathrm{mg} / \mathrm{kg} \mathrm{RV}+\mathrm{CXP}$ group showed decreased mRNA levels of $N F \kappa B, I L 1 \beta$, and IL6 (1.63 \pm 0.14 vs. $1.26 \pm 0.10, p=0.04$ for $N F \kappa B, 2.22 \pm$ 0.39 vs. $0.78 \pm 0.22, p=0.006$ for IL1 $\beta$ and $2.25 \pm 0.24$ vs. $1.35 \pm 0.24, p=0.018$ for IL6). The $50 \mathrm{mg} / \mathrm{kg}$ RV + CXP group did not show any significant difference in mRNA levels of $N F \kappa B$, IL1 $\beta$, and IL6 compared to the CXP group.

The mRNA expression level of CYP1A1 was increased in the $0.5 \mathrm{mg} / \mathrm{kg}$ RV group but decreased in the CXP group compared to the control group ( $2.1 \pm 0.27$ vs. $1.0 \pm 0.08$, $p=0.003$ for the $0.5 \mathrm{mg} / \mathrm{kg} \mathrm{RV}$ group and $0.68 \pm 0.05$. vs. $1.0 \pm 0.08, p=0.006$ for CXP group). CYP1A1 mRNA level, which was decreased in the CXP group, was increased in the $0.5 \mathrm{mg} / \mathrm{kg} \mathrm{RV}+\mathrm{CXP}$ group but not in the $50 \mathrm{mg} / \mathrm{kg}$ RV + CXP group $(2.0 \pm 0.13 \mathrm{vs}$. $0.68 \pm 0.05, p<0.001)$.

\subsection{Decreased AhR Protein and Nuclear/Cytosolic RAGE Levels Following RV Administration}

AhR protein levels decreased following administration of a high dose of RV (Figure 4). The $50 \mathrm{mg} / \mathrm{kg}$ RV group showed lower AhR protein level compared to the control group $(0.44 \pm 0.17$ fold, $p=0.006)$. CXP administration increased the AhR protein level in the CXP group and the $50 \mathrm{mg} / \mathrm{kg} \mathrm{RV}+$ CXP groups $(1.40 \pm 0.11$ fold, $p=0.019$ for CXP group and $1.47 \pm 0.10$ fold, $p=0.003$ for the $50 \mathrm{mg} / \mathrm{kg} \mathrm{RV}+\mathrm{CXP}$ group). AhR protein levels showed a decreased tendency in the $0.5 \mathrm{mg} / \mathrm{kg} \mathrm{RV}$ group and an increased tendency in the $0.5 \mathrm{mg} / \mathrm{kg} \mathrm{RV}+\mathrm{CXP}$ group compared to the control group, although there was no statistical significance $(0.52 \pm 0.25$ fold, $p=0.0 .7$ for the $0.5 \mathrm{mg} / \mathrm{kg} \mathrm{RV}$ group and $1.40 \pm$ 0.16 fold, $p=0.053$ for the $0.5 \mathrm{mg} / \mathrm{kg} \mathrm{RV}+\mathrm{CXP}$ group)

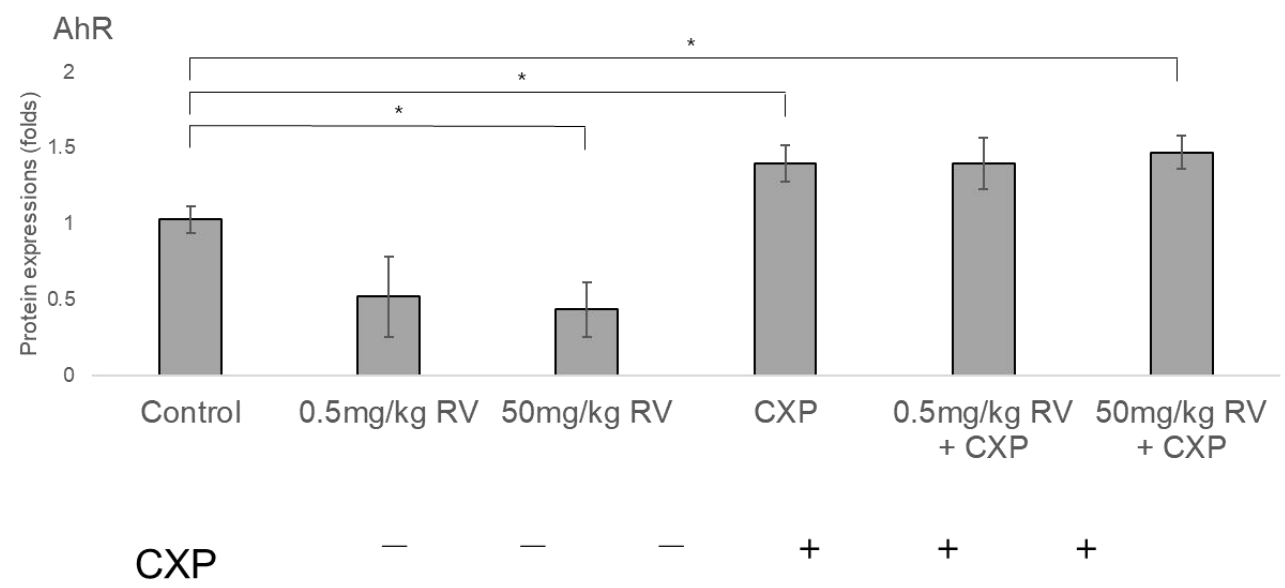

$\mathrm{RV}(\mathrm{mg} / \mathrm{kg}) \quad-\quad 0.5 \quad 50 \quad-\quad 0.5 \quad 50$

AhR

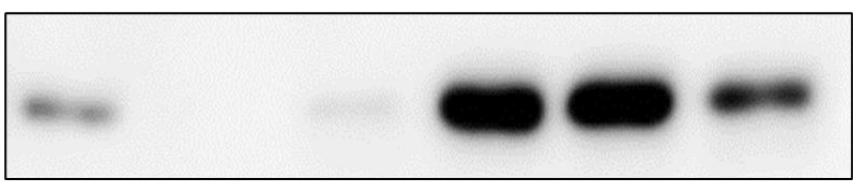

$\beta$-Actin

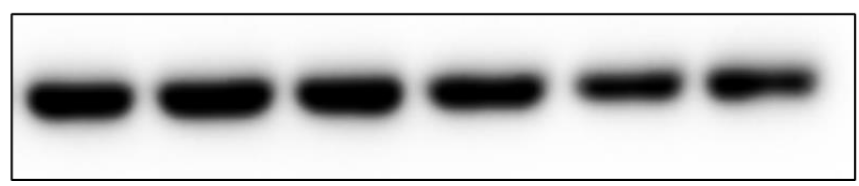

Figure 4. The administration of RV decreased the AhR protein levels. On the other hand, CXP administration increased the AhR protein level ( ${ }^{*} p<0.05$, compared to the control group).

Cytosolic RAGE protein level decreased following administration of a high dose of $\mathrm{RV}$ (Figure 5). The $50 \mathrm{mg} / \mathrm{kg} \mathrm{RV}$ group showed significantly lower cytosolic RAGE protein level compared to the control group $(0.32 \pm 0.06$ fold, $p=0.001)$. The CXP group did not show any significant difference in cytosolic RAGE protein level compared to the control group $(1.11 \pm 0.22$ fold, $p=0.28)$. Both $0.5 \mathrm{mg} / \mathrm{kg} \mathrm{RV}+\mathrm{CXP}$ and $50 \mathrm{mg} / \mathrm{kg} \mathrm{RV}+\mathrm{CXP}$ 
groups showed lower cytosolic RAGE protein levels compared to the control group ( $0.60 \pm$ 0.08 fold, $p=0.03$ for the $0.5 \mathrm{mg} / \mathrm{kg}$ RV + CXP group and $0.47 \pm 0.06$ fold, $p=0.001$ for the $50 \mathrm{mg} / \mathrm{kg} \mathrm{RV}+$ CXP group). The nuclear RAGE protein levels were not different among the groups.
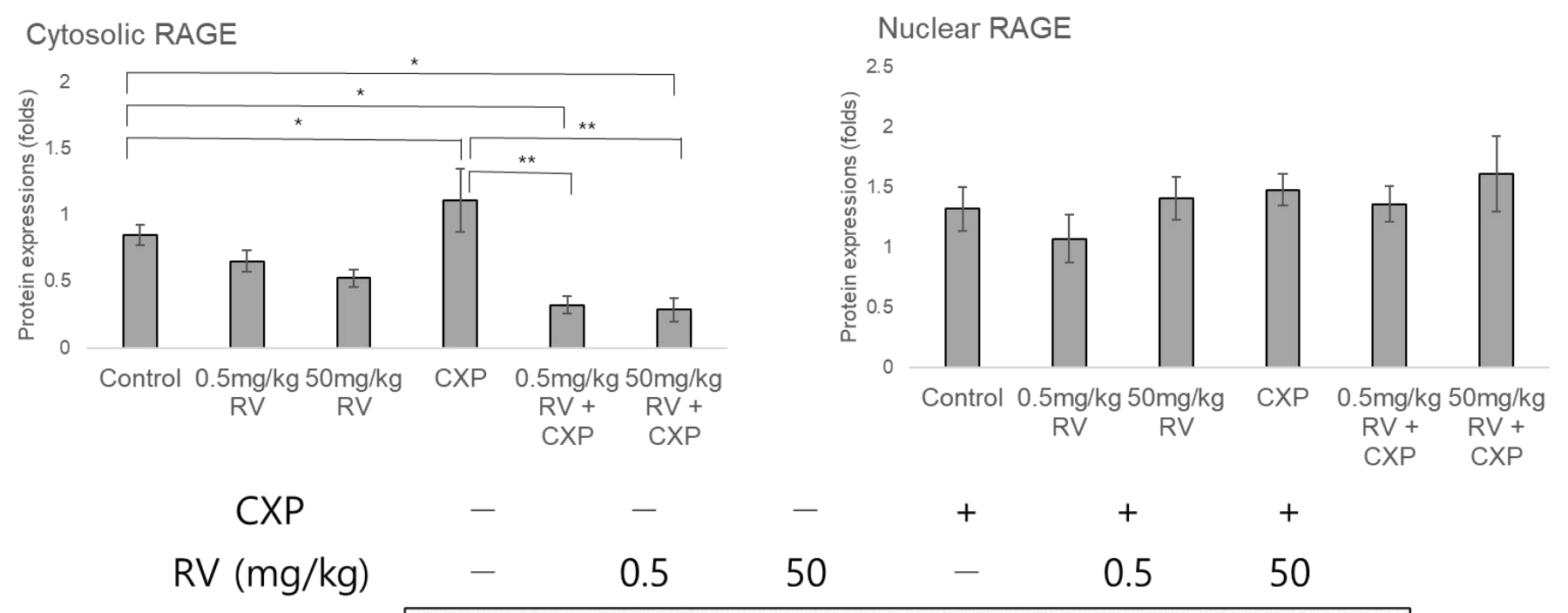

Cytosolic RAGE

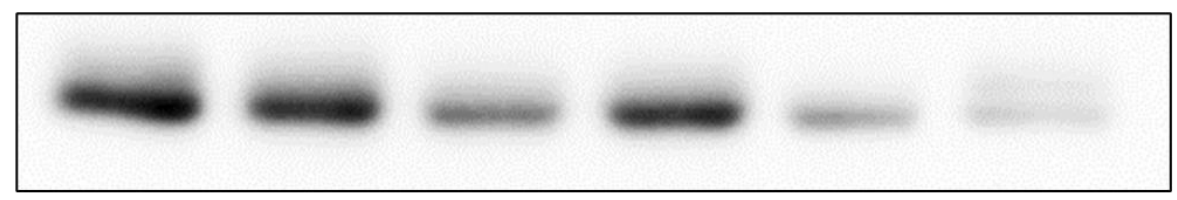

Nuclear RAGE
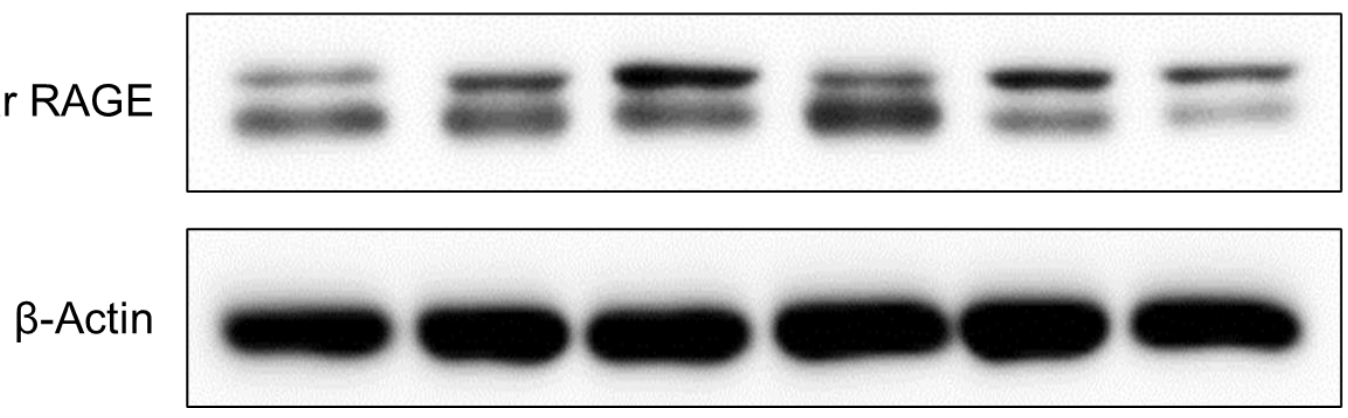

Figure 5. Cytosolic RAGE protein level decreased following administration of a $50 \mathrm{mg} / \mathrm{kg}$ of resveratrol (RV). Both $0.5 \mathrm{mg} / \mathrm{kg} \mathrm{RV}+\mathrm{CXP}$ and $50 \mathrm{mg} / \mathrm{kg} \mathrm{RV}+\mathrm{CXP}$ groups showed lower cytosolic RAGE protein levels compared to the control group. ( ${ }^{*} p<0.05$, compared to the control group, ${ }^{* *} p<0.05$, compared to the CXP group)

\section{Discussion}

In this study, we demonstrated that low-dose RV partially reduced the auditory threshold shifts in CXP-induced hearing loss rats. The increased expression of the proinflammatory cytokines IL1 $\beta$, IL6, and cytosolic RAGE in CXP rats were attenuated in the low-dose RV + CXP rats. Low-dose RV elevated CYP1A1 transcript and the decreased CYP1A1 mRNA expression in CXP rats was reversed following co-administration of lowdose RV with CXP. In contrast, high-dose RV increased the auditory thresholds. High-dose RV did not attenuate the mRNA expression levels of pro-inflammatory cytokines. Highdose RV alone elevated the mRNA expression level of NFKB. Both low- and high-dose RV alone decreased AhR and cytosolic RAGE protein levels. Although they did not reduce AhR, cytosolic RAGE expression was decreased in the groups co-administered high or low doses of RV along with CXP. By investigating the dose-dependent otoprotective effects of RV on relevant molecules, this study contributes substantially to the existing body of knowledge in the field. 
In this study, we found that low-dose RV reduced hearing loss and inflammatory responses. A few prior studies have reported the otoprotective effects of low to moderate doses of RV [9,10,13,15,17,18]. Long-term administration of RV reduced age-related hearing loss in mice by protecting the cochlear hair cells, spiral ganglion cells, and stria vascularis [9]. In the study, the authors demonstrated that these effects of RV were mediated through activation of SIRT1, which rebalanced mitochondrial biogenesis and mitophagy to overcome oxidative stress [9]. An in vitro study also demonstrated the anti-oxidative effects of RV mediated through activation of mitochondrial biogenesis in mouse cochlea and HEI-OC1 cells [10]. The anti-oxidative effects of RV $(5 \mathrm{mg} / \mathrm{kg})$ were also validated in noiseinduced hearing loss rats that reduced reactive oxygen species (ROS) and cyclooxygenase 2 levels [13]. Aminoglycoside-induced hearing loss was also prevented by administration of RV $(10 \mathrm{mg} / \mathrm{kg})$ through the modulation of genes associated with oxidative (glutathione peroxidase 1 , superoxide dismutase 1 , copper chaperone for superoxide dismutase, and NADPH oxidase activator 1 ) and inflammatory responses (IL1 $\beta$, IL4, myeloperoxidase, and neutrophil cytosolic factor 1) [15]. Reduced ROS and hearing preservation have been reported in cisplatin-induced hearing loss in guinea pigs and rats following administration of $10 \mathrm{mg} / \mathrm{kg}$ of RV [17,18]. In contrast, RV was shown to mediate ototoxic effects at high doses [20]. To the best of our knowledge, no prior study has investigated the ototoxic effect of RV. The results of our study imply that high doses of RV induce inflammatory responses associated with the expression of $N F \kappa B, I L 6$, and $I L 1 \beta$.

The hearing preservation effects of low-dose RV observed in this study may be mediated by the anti-inflammatory effects of $N F \kappa B, I L 6$, and IL1 $\beta$, and anti-oxidative effects of CYP1A1 and cytosolic RAGE. CXP increases oxidative stress and the pro-inflammatory cytokines NFKB and IL6 [23]. RV has been reported to decrease RAGE and NFKB activities, thereby restoring oxidative stress and inflammation-related diseases [24]. In diabetic rats, RAGE expression levels with malondialdehyde level, total oxidant, and plasma glucose, but not AGE level, were decreased following RV treatment [25]. In mouse macrophages, AGE and lipopolysaccharides stimulated RAGE, which induced NF- $\mathrm{kB}$ activation and pro-inflammatory cascades including IL6 and IL1 $\beta$, and RV reduced these inflammatory responses of RAGE/NFkB/IL6 and IL1 $\beta$ [26]. In the present study, CXP rats showed increased levels of AhR expression. This result is consistent with a previous study that demonstrated the increased AhR in cisplatin-induced rats [27]. The increased AhR expression in CXP rats was reversed by low-dose or high-dose RV administration in the present study. In line with these results, the AhR activated by the endogenous ligand of tryptophan metabolite-derived indoxyl sulfate and the subsequent AhR-mediated endothelial hyperpermeability were reversed by RV in bovine aortic endothelial cells [28].

The high dose of RV did not show otoprotective effects in the present study. A few previous studies have suggested the adverse effects of RV overdose $[8,29]$. The pro-oxidant effects of a high dose of RV could mediate the ototoxic effects in this study. The high levels of pro-inflammatory molecules of NFkB and IL6 and decrease of anti-oxidative molecule of CYP1A1 may mediate the ototoxic response of a high dose of RV in this study. Previous studies reported the pro-oxidant effects of a high dose of RV in the cardiovascular system $[30,31]$. Because activation of CYP1A1 was reported to be mediated by $A h R$, the suppression of AhR expression with a high dose of RV could be linked with the insufficient activation of CYP1A1 [32]. In addition, the exaggerated apoptotic effects of RV at high doses could hinder the otoprotective effects in this study. Both intrinsic and extrinsic apoptotic pathways are activated by RV [33]. Mitochondrial membrane potential, $\mathrm{Bax} / \mathrm{Bcl}-2$ ratio, and cleaved caspase- 8 and -3 were increased after RV administration [33]. In addition, unidentified metabolites of RV in vivo could impact the high-dose RV rats. In contrast to in vitro studies, the tissue concentrations of RV might be time-dependent, and pharmacokinetic-pharmacodynamic profiles, including the maximal concentration, threshold concentration, and total exposure over time, need to be considered in an in vivo study [34]. A previous study reported the ototoxic effect of resveratrol with a cumulative dose of $100 \mathrm{mg} / \mathrm{kg}$ (Table 1) [20]. However, another study reported an otoprotective effect 
of resveratrol with a cumulative dose of $100 \mathrm{mg} / \mathrm{kg}$ (Table 1) [35]. The cumulative dose up to $50 \mathrm{mg} / \mathrm{kg}$ of resveratrol might be otoprotective according to previous results [16-18,20]. The adequate dose of RV needs to be further evaluated in preclinical and clinical studies on the application of RV in hearing loss patients.

Table 1. Studies on the effects of resveratrol on the cisplatin-induced ototoxicity. i.p., intraperitoneal injection; N/A means not applicable.

\begin{tabular}{|c|c|c|c|c|c|}
\hline Animals & $\begin{array}{l}\text { Dose of Resveratrol } \\
(\mathrm{mg} / \mathrm{kg})\end{array}$ & $\begin{array}{l}\text { Cumulative } \\
\text { Dose }(\mathrm{mg} / \mathrm{kg})\end{array}$ & $\begin{array}{l}\text { Dose of } \\
\text { Cisplatin } \\
\text { (mg/kg) }\end{array}$ & $\begin{array}{c}\text { Ototoxic/ } \\
\text { Otoprotective }\end{array}$ & References \\
\hline SD 8-weeks rat & 0.5/day for 10 days (i.p.) & 5 & 3 for 5 days & Otoprotective & Current study \\
\hline Wistar albino rat & $\begin{array}{l}0.1,1 / \text { day for } 10 \text { days } \\
\text { (i.p.) }\end{array}$ & 1,10 & 16 & Otoprotective & Olgun Y. et al., 2014 [20] \\
\hline Adult albino guinea pig & 10/day for 2 days (i.p.) & 20 & 10 for 1 day & Otoprotective & $\begin{array}{l}\text { Yumusakhuylu A.C. et al., } \\
2013 \text { [17] }\end{array}$ \\
\hline $\begin{array}{l}\text { Wistar albino } \\
\text { 3-months rat }\end{array}$ & 10/day for 5 days (i.p.) & 50 & 12 & Otoprotective & Erdem T. et al., 2012 [18] \\
\hline Wistar rat & 100/day for 1 day (i.p.) & 100 & 15 & Otoprotective & Simsek G. et al. [35] \\
\hline $\begin{array}{c}\text { Albino-Wistar 3-months } \\
\text { rat }\end{array}$ & $\begin{array}{c}20 \mathrm{mg} / \mathrm{mL} \times 0.05 \\
\mathrm{~mL} / \text { day for } 1 \text { days (i.p.) }\end{array}$ & N/A & 15 for 1 day & Otoprotective & Simsek G. et al. [16] \\
\hline Wistar albino rat & $10 /$ day for 10 days (i.p.) & 100 & 16 & Ototoxic & Olgun Y. et al., 2014 [20] \\
\hline SD 8-weeks rat & 50/day for 10 days (i.p.) & 500 & 3 for 5 days & Ototoxic & Current study \\
\hline
\end{tabular}

\section{Materials and Methods}

\subsection{Experimental Design}

The animal experiments performed in this study were approved by the Institutional Animal Care and Use Committee of the CHA University Medical School (IACUC200025, approval date: 20191206). All experimental procedures complied with the guidelines of the Institutional Animal Care and Use Committee of the CHA University Medical School. Seventy-two female Sprague-Dawley rats (8-weeks old) were divided into six groups ( $n=12$ /group; Figure 6). The control group received $500 \mu \mathrm{L}$ of normal saline (intraperitoneal injection (i.p.)) every day for 10 days. The $0.5 \mathrm{mg} / \mathrm{kg} \mathrm{RV}$ group was administered $0.5 \mathrm{mg} / \mathrm{kg}$ of RV (i.p.) every day for 10 days. The $50 \mathrm{mg} / \mathrm{kg}$ RV group was administered $50 \mathrm{mg} / \mathrm{kg}$ of RV (i.p.) every day for 10 days. The cisplatin (CXP) group was administered CXP ( $3 \mathrm{mg} / \mathrm{kg} /$ day) (i.p.) for 5 days and then $500 \mu \mathrm{L}$ of normal saline (i.p.) every day for 5 days. The $0.5 \mathrm{mg} / \mathrm{kg} \mathrm{RV}+\mathrm{CXP}$ group was administered $0.5 \mathrm{mg} / \mathrm{kg}$ of RV along with $3 \mathrm{mg} / \mathrm{kg}$ of CXP (i.p.) every day for 5 days and then $0.5 \mathrm{mg} / \mathrm{kg}$ of RV (i.p.) every day for 5 days. The $50 \mathrm{mg} / \mathrm{kg} R V+C X P$ group was administered $50 \mathrm{mg} / \mathrm{kg}$ of RV along with $3 \mathrm{mg} / \mathrm{kg}$ of CXP (i.p.) every day for 5 days and then $50 \mathrm{mg} / \mathrm{kg}$ of RV (i.p.) every day for 5 days. The auditory brainstem response (ABR) thresholds were measured before ( $0-2$ days) and after (12-14 days) the drug administration schedule. All rats were sacrificed three days after the end of the drug administration schedule (15 days). No rats died during the experiments. 
8-week SD rats (200-250g):

- Control group $(n=12)$

- $0.5 \mathrm{mg} / \mathrm{kg}$ resveratrol (RV) group $(n=12)$

- $50 \mathrm{mg} / \mathrm{kg}$ RV group $(n=12)$

- Cisplatin (CXP) group $(n=12)$

- $0.5 \mathrm{mg} / \mathrm{kg} \mathrm{RV}+$ CXP group $(n=12)$

- $50 \mathrm{mg} / \mathrm{kg} \mathrm{RV}+\mathrm{CXP}$ group $(n=12)$

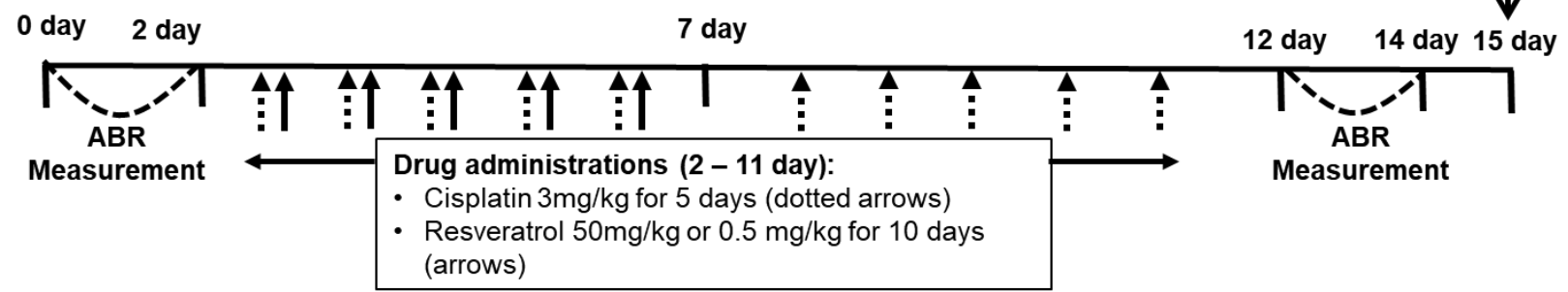

Figure 6. The experimental schedule of the present study. The cisplatin (CXP) group was administered CXP ( $3 \mathrm{mg} / \mathrm{kg} / \mathrm{day})$ for 5 days and then normal saline every day for 5 days. The RV + CXP groups were administered RV along with CXP every day for 5 days and then RV every day for 5 days.

\subsection{ABR Measurements}

The ABR thresholds at 4, 8, 16, and $32 \mathrm{kHz}$ were measured using the SmartEP system as described previously [23,24]. The rats were intraperitoneally administered zoletil $(40 \mathrm{mg} / \mathrm{kg})$ and xylazine $(10 \mathrm{mg} / \mathrm{kg})$ prior to the ABR measurements. The reference and ground electrodes were inserted at the vertex and contralateral thigh, and the measuring electrode was placed at the ipsilateral retroauricular area. Tone bursts of $4,8,16$, and $32 \mathrm{kHz}$ with durations of $1562 \mu$ s with Blackman envelope were applied at a stimulation rate of 21.2/s to the EC1 electrostatic speaker. The auditory-evoked responses of 1024 sweeps were averaged. The intensity of the sound stimuli was applied up to $90 \mathrm{~dB}$ SPL. The lowest sound intensity with wave III was defined as the ABR threshold.

\subsection{Cochlear Whole Mounts}

Outer hair cells were histologically examined using cochlear whole mounts. Two rats per group (total 24 ears for 12 rats) were used for cochlear whole mounts. The cochleae were fixed in $4 \%$ paraformaldehyde solution. After decalcification, the cochlear outer hair cells were dissected. Then, tissues were soaked in $0.3 \%$ Triton blocking solution. The 4',6-diamidino-2-phenylindole dihydrochloride (DAPI) solution was applied to the tissues for $1 \mathrm{~h}$, and the tissues were then mounted on slides and examined under a light microscope. The number and arrangement of cochlear outer hair cells were examined using confocal microscopy with a stack image under 400-fold magnification (Zeiss LSM 880, Zeiss, Oberkochen, Land Baden-Wurttemberg, Germany).

\section{4. mRNA Expression of Inflammatory Factors}

Five rats per group (a total of 60 ears of 30 rats) were used for quantitative reverse transcription-polymerase chain reaction (qRT-PCR). qRT-PCR was performed as described previously [25]. The membranous labyrinth tissues were collected and frozen in $\mathrm{NO}_{2}$ deep freezer. Total RNA was extracted within $24 \mathrm{~h}$ of tissue collection using TRIzol ${ }^{\mathrm{TM}}$ Reagent (Invitrogen, Waltham, MA, USA). The purified RNA was checked for purity and quantity by measuring the $260 / 280 \mathrm{~nm}$ absorbance ratio using a Micro UV-Vis spectrophotometer (Lifereal Biotechnology Corp. Ltd., Hangzhou, China). Only samples with a 260/280 ratio $>1.8$ and a 260/230 ratio > 1.5 were used for qRT-PCR. Maxime ${ }^{\text {TM }}$ RT Pre Mix (Oligo (dT)15 Primer) (iNtRON Biotechnology, Seongnam, Korea) was used for reverse transcription. Nuclear factor- $\kappa B(N F \kappa B)$, interleukin-1 $\beta$ (IL1 $\beta$ ), interleukin-6 (IL6), and cytochrome P450 1A1 (CYP1A1) were reverse transcribed and PCR-amplified using the primers listed in Table 2. Real-time reverse transcription (RT)-PCR was performed on a ViiA7 Real-time 
PCR system (Applied Biosystems, Carlsbad, CA, USA) using TOPreal ${ }^{\mathrm{TM}}$ qPCR $2 \times$ PreMIX (SYBR Green with low ROX; Enzynomics, Daejeon, Korea) using the following protocol: initial activation of HotStarTaq ${ }^{\circledR}$ DNA polymerase at $95^{\circ} \mathrm{C}$ for $15 \mathrm{~min}$, followed by 50 cycles of $95^{\circ} \mathrm{C}$ for $10 \mathrm{~s}, 60^{\circ} \mathrm{C}$ for $15 \mathrm{~s}$, and $72{ }^{\circ} \mathrm{C}$ for $15 \mathrm{~s}$. The amplification efficiency (E) of each amplicon was determined using a 10-fold serial dilution of positive control complementary DNA (cDNA) and calculated from the slopes of the log input amounts (20 ng-2 pg of cDNA) that were plotted according to the crossing point values using the formula $\mathrm{E}=10-$ 1 /slope. All primer efficiencies were confirmed to be high $(>90 \%)$ and comparable. The calculated mRNA levels were normalized to glyceraldehyde 3-phosphate dehydrogenase $(\mathrm{GAPDH})$ according to the formula $2^{-\Delta \Delta \mathrm{Ct}}$, and expressed as a percentage of the reference gene.

Table 2. Oligonucleotide primer sequences for quantitative reverse transcriptase polymerase chain reaction.

\begin{tabular}{|c|c|c|c|c|c|}
\hline Gene & Primer Sequence (Forward) & Primer Sequence (Reverse) & $\begin{array}{c}\text { Annealing } \\
\text { Temperature }\left({ }^{\circ} \mathrm{C}\right)\end{array}$ & $\begin{array}{l}\text { Product } \\
\text { Size (bp) }\end{array}$ & RefSeq Number \\
\hline IL6 & 5'-AGAGACTTCCAGCCAGTTGC-3' & 5'-TGAAGTCTCCTCTCCGGACT-3' & 60 & 88 & NM_012589.2 \\
\hline$I L 1 \beta$ & 5'-САССТТСТТТТССТТСАТСТTТG-3' & 5'-GTCGTTGCTTGTCTCTCCTTGTA-3' & 60 & 241 & NM_031512.2 \\
\hline$N F \kappa B$ & 5'-TGTCTGCACCTGTTCCAAAGA-3' & 5'-TGCCAGGTCTGTGAACACTC-3' & 60 & 143 & NM_199267.2 \\
\hline CYP1A1 & 5'-CATCССССАСАGCACCATAA-3' & 5'-TTCGCTTGCCCAAACCAAAG-3' & 60 & 212 & NM_012540.2 \\
\hline GAPDH & 5'-ATTGTTGCCATCAACGACCC-3' & 5'-TGACTGTGCCGTTGAACTTG-3' & 60 & 94 & NM_017008.4 \\
\hline
\end{tabular}

\subsection{Protein Levels of Aryl Hydrocarbon Receptor (AhR) and Receptor for Advanced Glycation Endproducts (RAGE)}

Five rats per group (a total of 60 ears of 30 rats) were used for Western blotting. Two rats per group (a total of 24 ears of 12 rats) were used to measure AhR protein level, and the remaining three rats in each group (total 36 ears of 18 rats) were used to measure protein levels of cytosolic/nuclear RAGE.

Nuclear and cytosolic fractions from cochlear tissue were extracted using the NEPER Nuclear Cytoplasmic Extraction Reagent kit (Pierce, Rockford, IL, USA). Briefly, the tissue was washed twice with cold PBS and centrifuged at $500 \times g$ for $5 \mathrm{~min}$. The pellet was resuspended in $400 \mu \mathrm{L}$ of cytoplasmic extraction reagent I by homogenizing. The suspension was then incubated on ice for $10 \mathrm{~min}$ followed by the addition of $22 \mu \mathrm{L}$ of cytoplasmic extraction reagent II. The mixture was vortexed for $5 \mathrm{~s}$, incubated on ice for $1 \mathrm{~min}$, and centrifuged for $5 \mathrm{~min}$ at $16,000 \times \mathrm{g}$. The supernatant (cytoplasmic extract) was transferred to a microcentrifuge tube. The insoluble pellet was resuspended in $200 \mu \mathrm{L}$ of nuclear extraction reagent by vortexing for $15 \mathrm{~s}$, incubated on ice for $10 \mathrm{~min}$, and centrifuged for $10 \mathrm{~min}$ at $16,000 \times \mathrm{g}$. The resulting supernatant constituted the nuclear extract.

Radioimmunoprecipitation assay buffer (Cell Signaling Technology, Danvers, MA, USA) was used for tissue lysis. The protein concentration was evaluated using a BioRad Protein Assay Kit. The proteins were separated using 8\% sodium dodecyl sulfatepolyacrylamide gel electrophoresis. Gels were transferred to polyvinylidene difluoride membranes (Merck Millipore, Burlington, MA, USA) and soaked in blocking buffer (5\% nonfat dry milk in Tris-buffered saline containing Tween-20 (TBS-T)) for $1 \mathrm{~h}$. The membrane was incubated in primary antibodies against AhR (mouse monoclonal, Santa Cruz Biotechnology, \#SC-133088), nuclear RAGE (ab3611, rabbit polyclonal, Abcam, Cambridge, MA, USA), cytosolic RAGE (MAB1179, Rat monoclonal, R\&D system, Minneapolis, MN, USA), $\beta$-actin (D6A8, rabbit mAb; Cell Signaling Technology, Danvers, MA, USA), and HDAC1 (sc47778, mouse, Santa Cruz, Dallas, TX, USA). The membranes were then incubated with the corresponding horseradish peroxidase (HRP)-conjugated secondary antibodies (anti-rabbit IgG, HRP-linked; Cell Signaling Technology, \#7074S and goat anti-mouse IgG H\&L (HRP); Abcam, \#ab97023). The protein bands were then visualized using an enhanced chemiluminescence kit (Bio-Rad, Hercules, CA, USA). Protein expression levels were calculated using ImageJ gel analysis software (National Institutes of Health, Bethesda, MD, USA) and compared with the expression levels of $\beta$-actin (for cytosolic proteins) or HDAC (for nuclear RAGE). 


\subsection{Statistical Analysis}

Changes in ABR thresholds were analyzed using paired $t$-test within each group and unpaired $t$-test between groups. The differences in mRNA and protein levels were analyzed using unpaired $t$-tests. The values are presented as mean \pm standard deviation. Statistical significance was defined as $p<0.05$. All analyses were performed using SPSS 21.0 (IBM Corp., Armonk, NY, USA).

\section{Conclusions}

Low-dose RV partially preserved hearing in cisplatin-induced hearing loss rats. The increased anti-oxidative effects involving CYP1A1 expression might be linked to the otoprotective effects of low-dose RV. The increased expression of pro-inflammatory cytokines IL6 and IL1 $\beta$ in CXP rats was attenuated in the low-dose RV + CXP rats. However, high-dose of RV did not exert otoprotective effects in CXP-induced hearing loss rats.

Author Contributions: Conceptualization, S.Y.K.; methodology, S.Y.K.; formal analysis, S.Y.K., S.M.L., and K.W.K. writing-original draft preparation, S.Y.K.; writing-review and editing, S.Y.K., C.H.L., K.W.K., and S.M.L.; funding acquisition, S.Y.K. and C.H.L. All authors have read and agreed to the published version of the manuscript.

Funding: This research was supported by funding from the National Research Foundation (NRF) of Korea (NRF- 2018R1D1A1B07048092 and 2020R1A2C4002594).

Institutional Review Board Statement: The study was conducted according to the guidelines of the Declaration of Helsinki, and approved by the the Institutional Animal Care and Use Committee of the CHA University Medical School (IACUC200025, 2019.12.06).

Data Availability Statement: The data presented in this study are available on request from the corresponding author.

Conflicts of Interest: The authors declare no conflict of interest. The funders had no role in the design of the study; in the collection, analyses, or interpretation of data; in the writing of the manuscript, or in the decision to publish the results.

\section{References}

1. Soleas, G.J.; Diamandis, E.P.; Goldberg, D.M. Resveratrol: A molecule whose time has come? And gone? Clin Biochem. 1997, 30, 91-113. [CrossRef]

2. Renaud, S.; de Lorgeril, M. Wine, alcohol, platelets, and the French paradox for coronary heart disease. Lancet 1992, 339, 1523-1526. [CrossRef]

3. Bonnefont-Rousselot, D. Resveratrol and Cardiovascular Diseases. Nutrients 2016, 8, 250. [CrossRef] [PubMed]

4. Catalgol, B.; Batirel, S.; Taga, Y.; Ozer, N.K. Resveratrol: French paradox revisited. Front Pharmacol. 2012, 3, 141. [CrossRef]

5. Walle, T.; Hsieh, F.; DeLegge, M.H.; Oatis, J.E., Jr.; Walle, U.K. High absorption but very low bioavailability of oral resveratrol in humans. Drug Metab. Dispos. 2004, 32, 1377-1382. [CrossRef]

6. Goldberg, D.M.; Yan, J.; Soleas, G.J. Absorption of three wine-related polyphenols in three different matrices by healthy subjects. Clin. Biochem. 2003, 36, 79-87. [CrossRef]

7. Aziz, M.H.; Reagan-Shaw, S.; Wu, J.; Longley, B.J.; Ahmad, N. Chemoprevention of skin cancer by grape constituent resveratrol: Relevance to human disease? FASEB J. 2005, 19, 1193-1195. [CrossRef]

8. Mukherjee, S.; Dudley, J.I.; Das, D.K. Dose-dependency of resveratrol in providing health benefits. Dose Response 2010, 8, 478-500. [CrossRef]

9. Xiong, H.; Chen, S.; Lai, L.; Yang, H.; Xu, Y.; Pang, J.; Su, Z.; Lin, H.; Zheng, Y. Modulation of miR-34a/SIRT1 signaling protects cochlear hair cells against oxidative stress and delays age-related hearing loss through coordinated regulation of mitophagy and mitochondrial biogenesis. Neurobiol. Aging 2019, 79, 30-42. [CrossRef]

10. Su, Z.; Xiong, H.; Pang, J.; Lin, H.; Lai, L.; Zhang, H.; Zhang, W.; Zheng, Y. LncRNA AW112010 Promotes Mitochondrial Biogenesis and Hair Cell Survival: Implications for Age-Related Hearing Loss. Oxid. Med. Cell. Longev. 2019, $2019,6150148$. [CrossRef]

11. Xiong, H.; Pang, J.; Yang, H.; Dai, M.; Liu, Y.-M.; Ou, Y.; Huang, Q.; Chen, S.; Zhang, Z.; Xu, Y.; et al. Activation of miR34a/SIRT1/p53 signaling contributes to cochlear hair cell apoptosis: Implications for age-related hearing loss. Neurobiol. Aging 2015, 36, 1692-1701. [CrossRef] [PubMed]

12. Xiong, H.; Ou, Y.; Xu, Y.; Huang, Q.; Pang, J.; Lai, L.; Zheng, Y. Resveratrol Promotes Recovery of Hearing following Intense Noise Exposure by Enhancing Cochlear SIRT1 Activity. Audiol. Neurootol. 2017, 22, 303-310. [CrossRef] [PubMed] 
13. Seidman, M.D.; Tang, W.; Bai, V.U.; Ahmad, N.; Jiang, H.; Media, J.; Patel, N.; Rubin, C.J.; Standring, R.T. Resveratrol decreases noise-induced cyclooxygenase-2 expression in the rat cochlea. Otolaryngol Head Neck Surg. 2013, 148, 827-833. [CrossRef] [PubMed]

14. Avci, D.; Erkan, M.; Sonmez, M.F.; Kokoglu, K.; Gunes, M.S.; Gundogdu, R.; Gulec, S.; Karabulut, D. A Prospective Experimental Study on the Protective Effect of Resveratrol against Amikacin-Induced Ototoxicity in Rats. J. Int. Adv. Otol. 2016, 12, $290-297$. [CrossRef]

15. Garcia-Alcantara, F.; Murillo-Cuesta, S.; Pulido, S.; Bermudez-Munoz, J.M.; Martinez-Vega, R.; Milo, M.; Varela-Nieto, I.; Rivera, T. The expression of oxidative stress response genes is modulated by a combination of resveratrol and $\mathrm{N}$-acetylcysteine to ameliorate ototoxicity in the rat cochlea. Hear Res. 2018, 358, 10-21. [CrossRef]

16. Simsek, G.; Tas, B.M.; Muluk, N.B.; Azman, M.; Kilic, R. Comparison of the protective efficacy between intratympanic dexamethasone and resveratrol treatments against cisplatin-induced ototoxicity: An experimental study. Eur. Arch. Otorhinolaryngol. 2019, 276, 3287-3293. [CrossRef]

17. Yumusakhuylu, A.C.; Yazici, M.; Sari, M.; Binnetoglu, A.; Kosemihal, E.; Akdas, F.; Sirvanci, S.; Yüksel, M.; Üneri, C.; Tutkun, A. Protective role of resveratrol against cisplatin induced ototoxicity in guinea pigs. Int. J. Pediatr. Otorhinolaryngol. 2012, 76, 404-408. [CrossRef]

18. Erdem, T.; Bayindir, T.; Filiz, A.; Iraz, M.; Selimoglu, E. The effect of resveratrol on the prevention of cisplatin ototoxicity. Eur. Arch. Otorhinolaryngol. 2012, 269, 2185-2188. [CrossRef]

19. Pang, J.; Xiong, H.; Ou, Y.; Yang, H.; Xu, Y.; Chen, S.; Lai, L.; Ye, Y.; Su, Z.; Lin, H.; et al. SIRT1 protects cochlear hair cell and delays age-related hearing loss via autophagy. Neurobiol. Aging 2019, 80, 127-137. [CrossRef]

20. Olgun, Y.; Kirkim, G.; Kolatan, E.; Kiray, M.; Bağriyanik, H.A.; Olgun, A.; Kızmazoglu, D.C.; Ellidokuz, H.; Serbetcioglu, B.; Altun, Z.S.; et al. Friend or foe? Effect of oral resveratrol on cisplatin ototoxicity. Laryngoscope 2014, 124, 760-766. [CrossRef]

21. Li, I.-H.; Shih, J.-H.; Jhao, Y.-T.; Chen, H.-C.; Chiu, C.-H.; Chen, C.-F.F.; Huang, Y.-S.; Shiue, C.-Y.; Ma, K.-H. Regulation of Noise-Induced Loss of Serotonin Transporters with Resveratrol in a Rat Model Using 4-[(18)F]-ADAM/Small-Animal Positron Emission Tomography. Molecules 2019, 24, 1344. [CrossRef] [PubMed]

22. Gu, J.; Wang, C.Q.; Fan, H.H.; Ding, H.Y.; Xie, X.L.; Xu, Y.M.; Wang, B.Y.; Huang, D.J. Effects of resveratrol on endothelial progenitor cells and their contributions to reendothelialization in intima-injured rats. J. Cardiovasc. Pharmacol. 2006, 47, 711-721. [CrossRef]

23. Lee, C.H.; Lee, D.-H.; Lee, S.M.; Kim, S.Y. Otoprotective Effects of Zingerone on Cisplatin-Induced Ototoxicity. Int. J. Mol. Sci. 2020, 21, 3503. [CrossRef] [PubMed]

24. Hajizadeh-Sharafabad, F.; Sahebkar, A.; Zabetian-Targhi, F.; Maleki, V. The impact of resveratrol on toxicity and related complications of advanced glycation end products: A systematic review. Biofactors 2019, 45, 651-665. [CrossRef] [PubMed]

25. Hajizadeh-Sharafabad, F.; Sahebkar, A.; Zabetian-Targhi, F.; Alizadeh, M. Effects of Resveratrol on Receptor for Advanced Glycation End Products (RAGE) Expression and Oxidative Stress in the Liver of Rats with Type 2 Diabetes. Phytother. Res. 2016, 30, 66-71. [CrossRef]

26. Ohtsu, A.; Shibutani, Y.; Seno, K.; Iwata, H.; Kuwayama, T.; Shirasuna, K. Advanced glycation end products and lipopolysaccharides stimulate interleukin-6 secretion via the RAGE/TLR4-NF-kappaB-ROS pathways and resveratrol attenuates these inflammatory responses in mouse macrophages. Exp. Ther. Med. 2017, 14, 4363-4370. [CrossRef]

27. Lee, C.H.; Park, S.-S.; Lee, D.-H.; Lee, S.M.; Kim, M.Y.; Choi, B.Y.; Kim, S.Y.; So, Y.K. Tauroursodeoxycholic acid attenuates cisplatin-induced hearing loss in rats. Neurosci. Lett. 2020, 722, 134838. [CrossRef]

28. Assefa, E.G.; Yan, Q.; Gezahegn, S.B.; Salissou, M.T.M.; He, S.; Wu, N.; Zuo, X.; Ying, C. Role of Resveratrol on Indoxyl SulfateInduced Endothelial Hyperpermeability via Aryl Hydrocarbon Receptor (AHR)/Src-Dependent Pathway. Oxid. Med. Cell. Longev. 2019, 2019, 5847040. [CrossRef]

29. Scott, E.; Steward, W.P.; Gescher, A.J.; Brown, K. Resveratrol in human cancer chemoprevention-choosing the 'right' dose. Mol. Nutr. Food Res. 2012, 56, 7-13. [CrossRef]

30. Dudley, J.; Das, S.; Mukherjee, S.; Das, D.K. Resveratrol, a unique phytoalexin present in red wine, delivers either survival signal or death signal to the ischemic myocardium depending on dose. J. Nutr. Biochem. 2009, 20, 443-452. [CrossRef] [PubMed]

31. Wilson, T.; Knight, T.J.; Beitz, D.C.; Lewis, D.S.; Engen, R.L. Resveratrol promotes atherosclerosis in hypercholesterolemic rabbits. Life Sci. 1996, 59, PL15-PL21. [CrossRef]

32. Ye, W.; Chen, R.; Chen, X.; Huang, B.; Lin, R.; Xie, X.; Chen, J.; Jiang, J.; Deng, Y.; Wen, J. AhR regulates the expression of human cytochrome P450 1A1 (CYP1A1) by recruiting Sp1. FEBS J. 2019, 286, 4215-4231. [CrossRef] [PubMed]

33. Fan, Y.; Chiu, J.F.; Liu, J.; Deng, Y.; Xu, C.; Zhang, J.; Li, G. Resveratrol induces autophagy-dependent apoptosis in HL-60 cells. BMC Cancer 2018, 18, 581. [CrossRef] [PubMed]

34. Kapetanovic, I.M. Comment on 'Resveratrol in human cancer chemoprevention-choosing the 'right' dose'. Mol. Nutr. Food Res. 2012, 56, 523. [CrossRef] [PubMed]

35. Simsek, G.; Tokgoz, S.A.; Vuralkan, E.; Caliskan, M.; Besalti, O.; Akin, I. Protective effects of resveratrol on cisplatin-dependent inner-ear damage in rats. Eur. Arch. Otorhinolaryngol. 2013, 270, 1789-1793. [CrossRef] 